Abstracta Iranica Abstracta Iranica

Revue bibliographique pour le domaine irano-aryen

Volume 42-43 | 2021

Comptes rendus des publications de 2019-2020

\title{
Götz König. “Training in Thinking: Religious Criticism and the Use of Logic in Zoroastrian Theology"
}

Samra Azarnouche

\author{
(2) OpenEdition \\ Journals \\ Édition électronique \\ URL : https://journals.openedition.org/abstractairanica/54041 \\ DOI : 10.4000/abstractairanica. 54041 \\ ISSN : 1961-960X \\ Éditeur : \\ CNRS (UMR 7528 Mondes iraniens et indiens), Éditions de l'IFRI
}

Référence électronique

Samra Azarnouche, «Götz König. "Training in Thinking: Religious Criticism and the Use of Logic in Zoroastrian Theology" », Abstracta Iranica [En ligne], Volume 42-43 | 2021, document 10, mis en ligne le 30 décembre 2021, consulté le 13 décembre 2022. URL : http://journals.openedition.org/ abstractairanica/54041 ; DOI : https://doi.org/10.4000/abstractairanica.54041

Ce document a été généré automatiquement le 13 décembre 2022.

Tous droits réservés 


\title{
Götz König. "Training in Thinking: Religious Criticism and the Use of Logic in Zoroastrian Theology"
}

\author{
Samra Azarnouche
}

\section{RÉFÉRENCE}

Götz König. "Training in Thinking: Religious Criticism and the Use of Logic in Zoroastrian Theology" in Flavia Ruani, Mihaela Timuș (eds.). Quand les dualistes polémiquaient. Zoroastriens et manichéens. Leuven-Paris-Bristol: Peeters (Orient et Méditerranée 34), 2020, p. 65-82.

1 Comment les prêtres zoroastriens du début de l'islam ont employé les principes de la logique, et particulièrement le principe de non-contradiction, dans leur pratique argumentative de la controverse? L'A. rappelle que les textes zoroastriens ont toujours accordé une place importante au dialogue, soit en tant que mode de transmission du savoir sacré et rituel, soit comme genre indépendant dans les littératures moyen-perse et persane (textes pursišn passox), soit en tant que compétition intellectuelle. L'argumentation rationnelle tient un rang à part dans la polémique inter-religieuse telle qu'on la trouve chez des auteurs du IX ${ }^{\mathrm{e}}$ s., Ādurfarrbay et Mardānfarrox.

Plusieurs exemples éclairent les raisonnements des auteurs : les modes de perception qui servent à contredire la théorie moniste des musulmans (Dēnkard III.240); la défense de la dualité des principes, dō bun, (Dēnkard III.150), et la réfutation de la consubstantialité chrétienne (Dēnkard III.40, et Dādestān ì dēnīg 36.73). 


\section{AUTEURS}

SAMRA AZARNOUCHE

EPHE, CeRMI, Paris 